\title{
A study of small-colony, $\beta$-haemolytic, Lancefield group C streptococci within the anginosus group: description of Streptococcus constellatus subsp. pharyngis subsp. nov., associated with the human throat and pharyngitis
}

\author{
R. A. Whiley, ${ }^{1}$ L. M. C. Hall, ${ }^{2}$ J. M. Hardie' ${ }^{1}$ and D. Beighton ${ }^{3}$
}

Author for correspondence: R. A. Whiley. Tel: +44 1713777000 ext. 3219. Fax: +44 1712470657. e-mail: r.a.whiley@mds.qmw.ac.uk

1,2 Department of Oral Microbiology ${ }^{1}$ and Department of Medical Microbiology2, St Bartholomew's and the Royal London School of Medicine and Dentistry, London E1 2AD, UK

3 Joint Microbiological Research Unit, King's College School of Medicine and Dentistry, London SE5 9RW, UK

\begin{abstract}
$\beta$-Haemolytic, Lancefield group C streptococci within the anginosus-species group were shown by genetic and phenotypic criteria to be heterogeneous and to constitute two distinct taxa related at subspecies level to Streptococcus constellatus and Streptococcus anginosus, respectively. The first group. referred to here as DNA group 1, comprised six strains with $86-100 \%$ intragroup overall genomic DNA relatedness; five of the strains were originally isolated from the human throat and one was from an abdominal mass. They shared $61-77 \%$ DNA relatedness $\left(\Delta T_{m}\right.$ values $\left.=1.2-1.5{ }^{\circ} \mathrm{C}\right)$ with reference strains of $S$. constellatus and were clearly differentiated from $S$. constellatus (now named Streptococcus constellatus subsp. constellatus) by the ability to produce $\beta$ - $N$-acetylgalactosaminidase, $\beta$ - $N$-acetylglucosaminidase, $\beta$-D-fucosidase, $\beta$-D-galactosidase and $\beta$-D-glucosidase. The name $S$. constellatus subsp. pharyngis is proposed for these strains on the grounds that they are genetically and phenotypically distinct and exhibit a predeliction for the human throat, being isolated also from cases of pharyngitis. The DNA G+C content is 35-37 mol\%. The type strain is MM9889a' (= NCTC 13122'). The second group (DNA group 2) was formed by five $\beta$-haemolytic, Lancefield group C strains originally isolated from various human infections. DNA group 2 strains (81-100\% intragroup DNA relatedness) shared 60-72\% DNA relatedness $\left(\Delta T_{m}\right.$ values $\left.=2 \cdot 1-4 \cdot 1{ }^{\circ} \mathrm{C}\right)$ with $S$. anginosus strains $N C T C 10713^{\top}$ and MAS 283 but were not clearly differentiated phenotypically from S. anginosus, showed no clear pattern of clinical association, and therefore are not formally proposed as a new subspecies here.
\end{abstract}

Keywords: human throat, pharyngitis, Streptococcus constellatus subsp. pharyngis subsp. nov., Streptococcus constellatus subsp. constellatus

\section{INTRODUCTION}

Within the genus Streptococcus, the 'anginosus' group includes three relatively closely related species, Streptococcus anginosus, Streptococcus constellatus and Streptococcus intermedius as shown by DNADNA hybridization studies and 16S rRNA gene sequence analysis (Whiley \& Beighton, 1991; Kawamura et al., 1995). Collectively, these form part of the flora of the mouth and the female urogenital tract, are isolated from the gastrointestinal tract, and are frequently associated with purulent infections in humans (Whiley et al., 1992; Jacobs et al., 1995). Evidence of further taxonomic heterogeneity within the group has been supported by phenotypic and genotypic criteria that include biochemical and cultural characteristics (Winstanley et al., 1992; Bergman et al., 1995), long-chain fatty acid composition (Cookson et al., 1989), pyrolysis mass spectra (Winstanley et al., 1992), DNA hybridization (Whiley \& Hardie, 1989; Whiley et al., 1997), and rRNA-based studies (Doitt et al., 1994; Bergman et al., 1995; 
Table 1. DNA relatedness (\%) among strains

$\Delta T_{\mathrm{m}}$ values $\left({ }^{\circ} \mathrm{C}\right)$ are shown in parentheses.

\begin{tabular}{|c|c|c|c|c|c|c|c|}
\hline \multirow[t]{2}{*}{ Unlabelled DNA } & \multicolumn{7}{|c|}{ Labelled DNA } \\
\hline & MM9889a & I751s & MAS 624 & NMH3 & NCTC $10713^{\mathrm{T}}$ & NCDO $2226^{T}$ & NCDO $2227^{\mathrm{T}}$ \\
\hline \multicolumn{8}{|l|}{ DNA group 1} \\
\hline I751s & $97(1 \cdot 5)$ & 100 & 51 & 41 & 51 & 61 & 46 \\
\hline M5823 & $96(1 \cdot 0)$ & 100 & $51(7 \cdot 5)$ & 50 & 47 & 62 & 46 \\
\hline MM4055 & $98(0 \cdot 0)$ & 86 & & 46 & & 61 & 49 \\
\hline I1299 & 94 & 89 & & 43 & & & \\
\hline MM9889a & 100 & 89 & $49(6 \cdot 25)$ & & 58 & $74(1 \cdot 5)$ & 50 \\
\hline MM6375 & $100(1 \cdot 5)$ & 100 & & 50 & & 63 & \\
\hline \multicolumn{8}{|l|}{ S. constellatus } \\
\hline NCDO $2226^{\mathrm{T}}$ & $74(1 \cdot 2)$ & 77 & $50(7 \cdot 4)$ & 45 & $58(7 \cdot 9)$ & 100 & $56(8 \cdot 0)$ \\
\hline NCTC 10714 & $72(1 \cdot 2)$ & & 51 & 39 & 44 & 85 & \\
\hline \multicolumn{8}{|l|}{ DNA group 2} \\
\hline MAS624 & 58 & & 100 & 91 & $72(2 \cdot 2)$ & & \\
\hline NMH3 & & 55 & & 100 & 69 & & \\
\hline MAS158 & $57(4 \cdot 5)$ & & $88(0 \cdot 0)$ & 86 & 63 & 48 & 44 \\
\hline W558 & & 56 & $90(0 \cdot 1)$ & 81 & 67 & & \\
\hline MM5068 & $57(5 \cdot 0)$ & & $100(0 \cdot 0)$ & 100 & $67(2 \cdot 1)$ & 49 & 42 \\
\hline \multicolumn{8}{|l|}{ S. anginosus } \\
\hline NCTC $10713^{\mathrm{T}}$ & $50(6 \cdot 4)$ & $55(6 \cdot 5)$ & $67(4 \cdot 1)$ & 60 & 100 & 44 & 36 \\
\hline MAS283 & 50 & 49 & & 62 & 65 & 43 & \\
\hline \multicolumn{8}{|l|}{ S. intermedius } \\
\hline NCDO $2227^{\mathrm{T}}$ & $55(2 \cdot 6)$ & 48 & $41(6 \cdot 0)$ & 42 & $43(9 \cdot 4)$ & 49 & 100 \\
\hline
\end{tabular}

Whiley et al., 1997). In a recent investigation undertaken in our laboratory, 21 strains identified as $S$. anginosus were shown to exhibit sufficient heterogeneity to warrant division at both species and subspecies level, although the numbers of strains belonging to these taxa were too few to support any formal taxonomic proposals (Whiley et al., 1997). Of particular interest in that study were four $\beta$-haemolytic, Lancefield group $C$ strains that formed two groups. The first group included two strains (I751s and M5823) with the following properties: they shared 100 and $60 \%$ DNA relatedness under optimum $\left(60^{\circ} \mathrm{C}\right)$ and stringent $\left(75^{\circ} \mathrm{C}\right)$ hybridization conditions, respectively; they possessed a $380 \mathrm{bp} 16 \mathrm{~S}-23 \mathrm{~S}$ rRNA (rRNA) intergenic spacer; they produced unique ribotype patterns from HindIII genomic digests; they were unusual in being able to produce $\beta$-galactosidase; and they shared less than $50 \%$ overall DNA relatedness with other anginosus-group strains tested under stringent hybridization conditions. The strains comprising the second group (strains NMH3 and W558) were characterized by a $600 \mathrm{bp}$ intergenic spacer, $\beta$ galactosidase activity, the production of hyaluronidase, and shared $87 \%$ interstrain DNA relatedness under stringent hybridization conditions. The latter data indicated that the second group might warrant subspecies status (Whiley et al., 1997).
In view of several reports on the possible clinical significance of Lancefield group $C$ strains that resembled $S$. anginosus (Lawrence et al., 1985; Fox et al., 1993; Vance, 1992; Willcox et al., 1993; Willcox, 1995), together with the fact that too few strains have been sufficiently characterized to allow any formal taxonomic proposals (Whiley et al., 1997), this study was undertaken with the purpose of clarifying the taxonomic position of these streptococci. On that basis, more extensive DNA reassociation studies and phenotypic characterization were applied to an increased number of strains.

\section{METHODS}

Bacterial strains and growth conditions. The following reference strains were used: the $S$. anginosus type strain, NCTC $10713^{\mathrm{T}}$ (ATCC $33397^{\mathrm{T}}$, DSM 20536 ${ }^{\mathrm{T}}$ ); the $S$. intermedius type strain, NCDO $2227^{\mathrm{T}}$ (NCTC $11324^{\mathrm{T}}$, ATCC $27225^{\mathrm{T}}$ ); the $S$. constellatus type strain, NCDO $2226^{\mathrm{T}}$ (NCTC $11325^{\mathrm{T}}$, ATCC $27823^{\mathrm{T}}$ ); and the $S$. constellatus reference strain, NCTC 10714. Clinical strains used were as follows: strains I751s and I1299 (from throats) and M5823 (from an abdominal mass) were originally obtained from $\mathbf{T}$. Winstanley, Royal Hallamshire Hospital, Sheffield, UK; strain W558 (from an arm-burn swab) and strains MM4055, 
MM9889a, MM6375 and MM5068 (from the throats of subjects with pharyngitis) were obtained from the Department of Medical Microbiology, St Bartholomew's and the Royal London School of Medicine and Dentistry, London, UK; and strains MAS 158, MAS 624 and MAS 283 (from abdominal infections) were obtained from Dr Jan Jacobs, Department of Medical Microbiology, University Hospital of Maastricht, Maastricht, The Netherlands. Most of the strains were received as $\beta$-haemolytic, Lancefield group C (or Lancefield group $\mathrm{G}$ in the case of strains NCTC $10713^{\mathrm{T}}$ and MM5068) S. anginosus. There were some exceptions to this: strain MAS 283 belonged to Lancefield group C but was non-haemolytic; and the type strains NCDO $2226^{\mathrm{T}}(S$. constellatus) and NCDO $2227^{\mathrm{T}}$ (S. intermedius) were both serologically ungroupable against Lancefield grouping antisera and were non-haemolytic.

Strains were maintained in the laboratory on Columbia blood-agar plates (Gibco-BRL, Life Technologies) containing $5 \%(\mathrm{v} / \mathrm{v})$ defibrinated horse blood (TCS Microbiological), incubated at $37^{\circ} \mathrm{C}$ in an atmosphere containing, by volume, $20 \%$ hydrogen, $10 \% \mathrm{CO}_{2}$ and $70 \%$ nitrogen. Cells for large-scale preparation of DNA for hybridization experiments and DNA minipreps for PCR were obtained by growing strains in brain-heart infusion broth (Oxoid Unipath) as described previously (Whiley et al., 1997).

DNA reassociation and $\Delta T_{\mathrm{m}}$ determinations. DNA was prepared from approximately $3 \mathrm{~g}$ (wet wt) of cells according to the method originally described by Garvie (1976). DNA purities and concentrations were determined spectrophotometrically at $230,260,280$ and $300 \mathrm{~nm}$. Radioactive DNA was obtained by simultaneous labelling with both $\left[1^{\prime}, 2^{\prime}, 5\right.$ $\left.{ }^{3} \mathrm{H}\right] \mathrm{dCTP}$ and $\left[1^{\prime}, 2^{\prime}-{ }^{3} \mathrm{H}\right] \mathrm{dGTP}$ by nick translation using a commercial kit according the manufacturer's instructions (Amersham International).

Labelled DNA was prepared from the type strains of $S$. anginosus (NCTC $10713^{\mathrm{T}}$ ), S. constellatus (NCDO 2226 ${ }^{\mathrm{T}}$ ) and $S$. intermedius (NCDO $2227^{\mathrm{T}}$ ), and from $\beta$-haemolytic, Lancefield group C strains MM9889a, I751s, MAS 624 and NMH3. DNA relatedness was determined using the S1 nuclease-trichloracetic acid method (Grimont, 1988): briefly, approximately $10 \mathrm{ng}$ labelled and $75 \mu \mathrm{g}$ unlabelled DNA were heat-denatured in $0.042 \mathrm{M} \mathrm{NaCl}$, the final $\mathrm{NaCl}$ concentration was adjusted to $0.42 \mathrm{M}$ (final volume, $0.5 \mathrm{ml}$ ), and hybridization was allowed to proceed at $60^{\circ} \mathrm{C}$ for $18 \mathrm{~h}$. The $T_{\mathrm{m}}$ value (i.e. the temperature at which $50 \%$ of the reassociated DNA became hydrolysable by $\mathrm{S} 1$ nuclease) was determined for those strains from which radioactive reference DNA had been prepared; the $\Delta T_{\mathrm{m}}$ value (i.e. the difference between the $T_{\mathrm{m}}$ value of the homologous reaction and that of a heterologous reaction) was used to estimate the level of divergence between two strains (Brenner, 1978).

DNA base composition determinations. $\mathrm{G}+\mathrm{C}$ compositions were determined in $0.15 \mathrm{M} \mathrm{NaCl}$ and $0.015 \mathrm{M}$ trisodium citrate (standard saline citrate) by thermal melting (Marmur \& Doty, 1962) as previously described (Whiley \& Hardie, 1989).

PCR amplification of the 165-235 rRNA intergenic spacer regions. Cell growth, treatment, lysis and PCR amplification were performed as previously described (Whiley et al., 1995).

Phenotypic tests. All strains were tested for preformed enzyme activities ( $\beta$ - $N$-acetylgalactosaminidase, $\beta$ - $N$-acetylglucosaminidase, $\alpha$-arabinosidase, $\alpha$-L-fucosidase, $\beta$-Dfucosidase, $\alpha$-D-galactosidase, $\beta$-D-galactosidase, $\alpha$-D-glu- cosidase, $\beta$-D-glucosidase, $\beta$-D-glucuronidase and sialidase), for acid production from carbohydrate substrates (amygdalin, arbutin, inulin, $\beta$ - $N$-acetylglucosamine, lactose, mannitol, melibiose, sorbitol and raffinose), for the production of acetoin (Voges-Proskauer test) and for the hydrolysis of arginine and aesculin, as described previously (Beighton et al., 1991; Whiley \& Beighton, 1991). Tests for the activities of preformed enzymes on 4MU-linked fluorogenic substrates were carried out using cells suspended in $50 \mathrm{mM}$ TES buffer ( $\mathrm{pH} \mathrm{7.5)}$ to an optical density of 0.4 at $620 \mathrm{~nm}$ and were scored by visual assessment as either positive (including weak activities above that of the negative controls) or negative. Hyaluronidase activity was detected using the method of Smith \& Willet (1968). Lancefield serological group reactions were detected with a commercial kit (Oxoid Unipath). Haemolytic reactions were determined on layered Columbia blood-agar plates (Gibco-BRL, Life Technologies) containing $5 \%(\mathrm{v} / \mathrm{v})$ defibrinated horse blood (TCS Microbiological), incubated anaerobically at $37^{\circ} \mathrm{C}$ for 24 and $48 \mathrm{~h}$.

Those strains that had been received together with accompanying biochemical or cultural data were, nevertheless, reexamined in all the above tests at the commencement of this study and the results obtained reported here.

\section{RESULTS}

\section{DNA reassociation and $\Delta T_{\mathrm{m}}$ determinations}

The results of these experiments are shown in Table 1. All of the $\beta$-haemolytic, Lancefield group C strains fell into one of two DNA reassociation groups (referred to as DNA groups 1 and 2 for the purposes of this communication), each showing $\geqslant 81 \%$ intragroup overall genomic sequence relatedness and $\Delta T_{\mathrm{m}}$ values of $\leqslant 5{ }^{\circ} \mathrm{C}$. Intergroup DNA relatedness values for these two DNA groups were $41-58 \%$ and $\Delta T_{\mathrm{m}}$ values were $4 \cdot 5-7.5^{\circ} \mathrm{C}$. DNA group 1 included $\beta$-haemolytic, Lancefield group C strains I751s, M5823, MM4055, I1299, MM9889a and MM6375 while DNA group 2 comprised Lancefield group C strains NMH3, MAS 624, MAS 158 and W558 together with Lancefield group $\mathrm{G}$ strain MM5068.

DNA group 1 also exhibited a weaker, although still relatively close, relationship with $S$. constellatus strains NCDO $2226^{\mathrm{T}}$ and NCTC 10714 , with overall reassociation values of $61-77 \%$ and $\Delta T_{\mathrm{m}}$ values of $1 \cdot 2-1 \cdot 5{ }^{\circ} \mathrm{C}$. DNA group 2 shared $60-72 \%$ DNA relatedness and showed $\Delta T_{\mathrm{m}}$ values of $2 \cdot 1-4 \cdot 1{ }^{\circ} \mathrm{C}$ with S. anginosus strains NCTC $10713^{\mathrm{T}}$ and MAS 283 . Reassociation levels with $S$. intermedius type strain $\mathrm{NCDO} 2227^{\mathrm{T}}$ were $46-55 \%\left(\Delta T_{\mathrm{m}}=2.6^{\circ} \mathrm{C}\right)$ and $41-$ $44 \%\left(\Delta T_{\mathrm{m}}=6.0^{\circ} \mathrm{C}\right)$ for DNA groups 1 and 2 , respectively.

\section{$16 S$ rRNA intergenic spacer-size determinations}

All strains in DNA group 1 produced a 380 bp PCR product, as did both of the $S$. constellatus strains tested (NCDO 2226 $6^{\mathrm{T}}$ and NCTC 10714). The DNA group 2 strains all produced a $600 \mathrm{bp}$ product, S. anginosus strains NCTC $10713^{\mathrm{T}}$ and MAS 283 gave a $450 \mathrm{bp}$ 
product, and the type strain of $S$. intermedius, NCDO $2227^{\mathrm{T}}$, gave a $330 \mathrm{bp}$ PCR product.

\section{Phenotypic characterization}

All strains were positive in the Voges-Proskauer test and did not produce $\alpha$-D-arabinosidase, $\alpha$-Lfucosidase, $\alpha$-D-galactosidase or $\beta$-D-glucuronidase. All strains produced acid from $\beta$-D- $N$-acetylglucosamine, and both hydrolysed arginine and aesculin. Acid was not produced from inulin, mannitol, raffinose, sorbitol or melibiose. The variable reactions for the strains studied, including typical test results for $S$. anginosus, $S$. constellatus and $S$. intermedius obtained using the test methods employed here, are shown in Table 2.

\section{DISCUSSION}

The results of the DNA relatedness studies demonstrate a close relationship between DNA group 1 and $S$. constellatus, and between DNA group 2 and $S$. anginosus. We believe that the $61-77 \%$ range in DNA relatedness and the $\Delta T_{\mathrm{m}}$ values of $1 \cdot 2-1 \cdot 5^{\circ} \mathrm{C}$ obtained between DNA group 1 strains and $S$. constellatus, when considered along with the high intra-DNA group 1 levels $(86-100 \%)$ and lower $\Delta T_{\mathrm{m}}$ values $\left(0 \cdot 0-1 \cdot 5^{\circ} \mathrm{C}\right)$, allows for the division of $S$. constellatus into two subspecies, according to currently accepted guidelines (Wayne et al., 1987; Grimont, 1988). The DNA reassociation data in this case are supported by clear discrimination of DNA group 1 strains from 'typical' $S$. constellatus strains on the basis of phenotypic testing; we feel that the proposal to recognize these strains as a distinct subspecies is further justified on clinical grounds by the fact that they exhibit an association with human throats and pharyngitis in particular.

The situation with DNA group 2 strains is different. Although these form a discrete sub-group, having a close relationship to $S$. anginosus (on the basis of DNA reassociation), and are characterized by a distinctive 600 bp 16S-23S rRNA intergenic spacer, as previously described (Whiley et al., 1995), their unequivocal differentiation by biochemical testing is not possible at present. On the one hand, these strains have $\beta$-Dgalactosidase activity (in contrast to 'typical' $S$. anginosus strains) but on the other hand, it has been demonstrated that the results of this test can be strongly influenced by the incubation conditions employed (Ahmet et al., 1995). At best, only a single phenotypic test difference has been found between these and other $S$. anginosus strains (under our experimental conditions) and no distinct pattern of association with particular clinical infections or anatomical sites has been observed so far; consequently, there are insufficient grounds for proposing subspecies status for DNA group 2 strains at present. On the basis of the DNA reassociation data reported here from reciprocal experiments, DNA groups 1 and 2 are clearly less closely related to $S$. intermedius. This observation supports our previously reported conclusions regarding the DNA relatedness of these taxa (Whiley et al., 1997). The surprisingly low $\Delta T_{\mathrm{m}}$ value of $2.6^{\circ} \mathrm{C}$ between DNA group 1 strains MM9889a and NCDO $2227^{\mathrm{T}}$, though still significantly greater than the $0 \cdot 0-1.5{ }^{\circ} \mathrm{C}$ range obtained between DNA group 1 strains, requires confirmation in future taxonomic studies on these streptococci. The doubt cast by us previously on the suitability of strain NCTC $10713^{\mathrm{T}}$ as the type strain of $S$. anginosus is reinforced here by the low reassociation level $(65 \%)$ obtained with a typical $S$. anginosus strain (MAS 283). This observation further supports our decision, here, not to make limited taxonomic proposals for $S$. anginosus; this species clearly needs to be the subject of a larger study involving many more strains. Virtually all of the results obtained here confirm or extend those obtained in our previous study (Whiley et al., 1997): in the latter case, DNA reassociation experiments performed under optimum $\left(60^{\circ} \mathrm{C}\right)$ and stringent $\left(75^{\circ} \mathrm{C}\right)$ conditions gave 100 and $60 \%$ homology, respectively, between strains I751s and M5823 (both were within homology group 1 in the present study) and $87 \%$ homology between strains W558 and NMH3 (both were within DNA group 2 in the present study). We have now determined (by agarose gel electrophoresis) that the low reassociation level $(16 \%)$ previously obtained between strain I751s and $S$. constellatus type strain NCDO $2226^{\mathrm{T}}$ was the result of degradation of the DNA preparation that was being used at the time; this problem led to the erroneous conclusion in that paper that strains I751s and M5823 were representatives of a new species (Whiley et al., 1997). In contrast, the subspecies-level relationship between DNA group 1 strains and strain NCDO $2226^{\mathrm{T}}$ revealed in the present study is also supported by the result obtained here between $S$. constellatus reference strain NCTC 10714 and another DNA group 1 strain, MM9889a (72\% DNA relatedness, $\Delta T_{\mathrm{m}}=1.2{ }^{\circ} \mathrm{C}$ ) and also by the presence of a $380 \mathrm{bp} 16 \mathrm{~S}-23 \mathrm{~S}$ rRNA intergenic spacer within DNA group 1 strains and $S$. constellatus, as shown previously (Whiley et al., 1995). Furthermore, the low DNA reassociation levels [22\% (optimum) and $20 \%$ (stringent)] obtained previously between $S$. anginosus type strain NCTC $10713^{\mathrm{T}}$ and strain NCDO $2226^{\mathrm{T}}$ when inadvertently using the degraded DNA from strain NCDO $2226^{\mathrm{T}}$, are in contrast to the significantly higher values consistently obtained between these two strains in both the present study and on other previous occasions (Whiley \& Hardie, 1989).

The biochemical test results reveal that the majority of the DNA group 1 strains produce hyaluronidase, with the exception of strains I751s and M5823 (which have remained negative for this characteristic in repeated testing). The initial impression gained during our previous study when only these two strains were available for examination, namely, that this taxon was characteristically hyaluronidase-negative, has not been confirmed here; this vindicates the decision made then 


\section{Table 2. Biochemical characteristics of strains}

Abbreviations refer to the production of the following: Haem, haemolysis on blood agar; Hyal, hyaluronidase; $\beta$-D-fuc, $\beta$-Dfucosidase; $\beta$-NA gal, $\beta$ - $N$-acetylgalactosaminidase; Sial, sialidase (neuraminidase); $\beta$-NA glu, $\beta$ - $N$-acetylglucosaminidase; $\alpha$-Dglu, $\alpha$-D-acetylglucosaminidase; $\beta$-D-glu, $\beta$-D-glucosidase; $\beta$-D-gal, $\beta$-D-galactosidase; Amyg, acid from amygdalin; Arb, acid from arbutin; Lac, acid from lactose. Typical species reactions are taken from Whiley \& Beighton (1991). NG, non-groupable against Lancefield grouping antisera; $\mathrm{NH}$, non-haemolytic.

\begin{tabular}{|c|c|c|c|c|c|c|c|c|c|c|c|c|c|}
\hline Strain & $\begin{array}{c}\text { Lancefield } \\
\text { grp }\end{array}$ & Haem & Hyal & $\beta$-D-fuc & $\begin{array}{c}\beta-\mathbf{N A} \\
\text { gal }\end{array}$ & Sial & $\begin{array}{c}\boldsymbol{\beta} \text {-NA } \\
\text { glu }\end{array}$ & $\alpha$-D-glu & $\beta$-D-glu & $\beta$-D-gal & Amyg & Arb & Lac \\
\hline \multicolumn{14}{|l|}{ DNA group 1} \\
\hline I751s & $\mathrm{C}$ & $\beta$ & - & + & + & - & - & + & + & + & + & + & + \\
\hline M5823 & $\mathrm{C}$ & $\beta$ & - & + & + & - & + & + & + & + & + & + & + \\
\hline MM4055 & $\mathrm{C}$ & $\beta$ & + & + & + & - & + & + & + & + & + & + & + \\
\hline 11299 & $\mathrm{C}$ & $\beta$ & + & + & + & - & + & + & + & + & + & + & + \\
\hline MM9889a & $\mathrm{C}$ & $\beta$ & + & + & + & - & + & + & + & + & + & + & + \\
\hline MM6375 & $\mathrm{C}$ & $\beta$ & + & + & + & - & + & + & + & + & + & + & + \\
\hline \multicolumn{14}{|l|}{ S. constellatus } \\
\hline NCDO $2226^{\mathrm{T}}$ & $\mathrm{NG}$ & $\mathrm{NH}$ & + & - & - & - & - & + & - & -- & - & - & + \\
\hline NCTC 10714 & $\mathrm{~F}$ & $\beta$ & + & - & - & - & - & + & - & - & - & - & - \\
\hline $\begin{array}{l}\text { Typical species } \\
\text { reactions }\end{array}$ & $\begin{array}{l}\mathrm{F} / \mathrm{NG}(\mathrm{C}, \\
\mathrm{G}, \mathrm{A})\end{array}$ & $\begin{array}{l}\beta, \\
\mathrm{NH}\end{array}$ & + & - & - & - & - & + & - & - & \pm & + & \pm \\
\hline \multicolumn{14}{|l|}{ DNA group 2} \\
\hline NMH3 & $\mathrm{C}$ & $\beta$ & + & - & - & - & - & - & + & + & + & + & + \\
\hline MAS 624 & $\mathrm{C}$ & $\beta$ & + & - & - & - & + & - & + & + & + & + & + \\
\hline MAS 158 & $\mathrm{C}$ & $\beta$ & + & - & - & - & - & - & + & + & + & - & + \\
\hline W558 & $\mathrm{C}$ & $\beta$ & + & - & - & - & - & - & + & + & + & - & + \\
\hline MM5068 & $\mathrm{G}$ & $\beta$ & + & - & - & - & + & - & + & + & + & + & + \\
\hline \multicolumn{14}{|l|}{ S. anginosus } \\
\hline NCTC $10713^{\mathrm{T}}$ & G & $\beta$ & - & - & - & - & - & - & + & - & + & + & + \\
\hline MAS 283 & C & NH & - & - & - & - & - & - & + & - & + & + & + \\
\hline $\begin{array}{l}\text { Typical species } \\
\text { reactions }\end{array}$ & $\begin{array}{l}\mathrm{F} / \mathrm{NG}(\mathrm{C}, \\
\quad \mathrm{G}, \mathrm{A})\end{array}$ & $\begin{array}{c}\mathrm{NH} \\
\beta\end{array}$ & - & - & - & - & - & \pm & + & - & + & + & + \\
\hline \multicolumn{14}{|l|}{ S. intermedius } \\
\hline NCDO $2227^{\mathrm{T}}$ & NG & NH & + & + & + & + & + & + & + & + & + & + & + \\
\hline $\begin{array}{l}\text { Typical species } \\
\text { reactions }\end{array}$ & $\mathrm{NG} / \mathrm{F}(\mathrm{C})$ & $\begin{array}{c}\mathrm{NH} \\
\beta\end{array}$ & + & + & + & + & + & + & \pm & + & \pm & + & + \\
\hline
\end{tabular}

not to make any formal taxonomic proposals until further strains had been studied.

We are aware that the present proposal to further divide $S$. constellatus into two subspecies may be considered by some to be unfounded in the belief that the anginosus group should be considered as a single species (Vandamme et al, 1998). We have previously acknowledged that members of this species group are relatively closely related when compared to many examples within the oral streptococci, but we cannot agree with the proposal that these should be reduced to single-species status. The levels of relatedness obtained by us with the $\mathrm{S} 1$ nuclease/trichloracetic acid approach in these experiments demonstrate unequivocally that the type strains of $S$. anginosus (NCTC $10713^{\mathrm{T}}$ ), $S$. constellatus (NCDO 2226 $6^{\mathrm{T}}$ ) and S. intermedius (NCDO $2227^{\mathrm{T}}$ ) represent separate species. We have observed this both when examining the group previously under optimum and stringent hybridization conditions
(Whiley \& Hardie, 1989; Whiley et al., 1997) and in the present study of $\Delta T_{\mathrm{m}}$ values. Similar conclusions have also been reached by other workers using the filter method for DNA hybridization (Kilpper-Bälz et al., 1984). The DNA homology data, together with the phenotypic differentiation of $S$. anginosus, $S$. constellatus and S. intermedius (Whiley \& Beighton, 1991; Ahmet et al., 1995; Jacobs et al., 1995) and the strong clinical association patterns for these taxa (Whiley et al., 1992; Jacobs et al., 1995), refute the idea that these constitute a single species. The evidence reported in this paper supports the further subdivision of $S$. constellatus into two subspecies.

Furthermore, it is clear to us from the results of this and our previous study that more taxa exist within the anginosus group than are currently recognized. It remains to be determined whether these taxa are distinct species and subspecies or constitute nodes within one large continuum of types; such clarification 
will require future examination of many more strains and intermediate/atypical isolates, and lies beyond the scope of this paper.

\section{Description of Streptococcus constellatus Prevot 1924 emend. Holdman and Moore 1974, emend. Whiley and Beighton 1991}

The description of Streptococcus constellatus is the same as that given by Whiley \& Beighton (1991) except that it is amended to include some strains producing $\beta-N$-acetylgalactosaminidase, $\beta-N$-acetylglucosaminidase, $\beta$-fucosidase, $\beta$-galactosidase and $\beta$-glucosidase. $S$. constellatus was described by Whiley \& Beighton (1991) as including very few strains producing $\beta$ galactosidase or $\beta$-glucosidase and no strains able to produce $\beta$ - $N$-acetylglucosaminidase or $\beta$-fucosidase. The proportion of strains producing $\beta$ - $N$-acetylgalactosaminidase was not included in the previous description.

\section{Description of Streptococcus constellatus subsp. constellatus subsp. nov.}

The description of Streptococcus constellatus subsp. constellatus is based on the previously reported characteristics of 50 clinical and reference strains of Streptococcus constellatus (emend.) (Whiley \& Beighton, 1991). This subspecies is the type subspecies of $S$. constellatus and contains the type strain according to Rules $40 \mathrm{a}$ and $40 \mathrm{~b}$ of the Bacteriological Code (Lapage et al., 1992).

Small $(0.5-1.0 \mu \mathrm{m}$ in diameter), Gram-positive, nonsporing, non-motile cocci in short chains. Catalasenegative. Colonies on blood agar are $0.5-2.0 \mathrm{~mm}$ in diameter, white or translucent, and convex with entire margins; some strains produce colonies that are $0.5-1.0 \mathrm{~mm}$ in diameter, white and matte. Growth is reduced under aerobic conditions and is frequently enhanced by the addition of $\mathrm{CO}_{2}$. Some strains require anaerobic conditions for growth. Acetoin is produced. Arginine and aesculin are hydrolysed, but urea is not. Hippurate is not split. Alkaline phosphatase and leucine arylamidase are produced. Most strains produce $\alpha$-glucosidase but very few produce $\beta$-galactosidase and $\beta$-glucosidase. $\beta$ - $N$-acetylglucosaminidase, $\beta$-D-fucosidase, $\alpha$-galactosidase, $\beta$-glucuronidase, pyrrolidonylarylamidase and sialidase are not produced. Acid is produced from glucose and frequently from salicin and trehalose. Lactose fermentation and amygdalin fermentation are variable characteristics of this species. A few strains produce acid from cellobiose, melibiose and raffinose. Arabinose, glycerol, inulin and sorbitol are not fermented. Few strains produce hydrogen peroxide. Most strains produce hyaluronidase. Strains are frequently $\beta$-haemolytic and belong to Lancefield group $F$ or are nonhaemolytic ( $\alpha$ and $\gamma$ ) and serologically ungroupable. A few strains react with Lancefield group A, C and G antisera. The habitats are oral cavities and upper respiratory tracts. Strains are isolated from human purulent infections including appendicitis. The DNA $\mathrm{G}+\mathrm{C}$ content is $37-38 \mathrm{~mol} \%$.

Description of the type strain. The type strain of Streptococcus constellatus subsp. constellatus is NCDO $2226^{\mathrm{T}}$ $\left(=\right.$ NCTC $11325^{\mathrm{T}}=$ ATCC $\left.27823^{\mathrm{T}}\right)$, which was the type strain of $S$. constellatus (Whiley \& Beighton, 1991). It has all of the uniform characteristics of the subspecies described above, is serologically upgroupable against Lancefield grouping antisera, is non-haemolytic, produces hyaluronidase and $\alpha$-glucosidase, and does not produce $\beta$-N-acetylglucosaminidase, $\beta$-D-fucosidase, $\alpha$-galactosidase, $\beta$-galactosidase, $\beta$-glucosidase, $\beta$-glucuronidase, pyrrolidonylarylamidase or sialidase. Lactose is fermented but amygdalin is not.

\section{Description of Streptococcus constellatus subsp. pharyngis subsp. nov.}

Streptococcus constellatus subsp. pharyngis (pha.ryn'gis. Gr. n. pharynx throat; Gr. gen. n. pharygnis of the throat).

The description below is based on the characteristics of the six strains included in this study. Small $(0 \cdot 5-1 \cdot 0 \mu \mathrm{m}$ in diameter), Gram-positive, non-spore-forming, nonmotile cocci in short chains. Catalase-negative. Colonies on blood agar are $0.5-2.0 \mathrm{~mm}$ in diameter, white or translucent, and convex with entire margins. Growth is reduced under aerobic conditions and is enhanced by the addition of $\mathrm{CO}_{2}$. Acetoin is produced. Arginine and aesculin are hydrolysed. Urea and hippurate are not hydrolysed. Alkaline phosphatase is produced. Strains produce $\beta$ - $N$-acetylgalactosaminidase, $\beta$-D-fucosidase, $\beta$-galactosidase, $\alpha$-glucosidase and $\beta$-glucosidase. The majority of strains produce $\beta$ - $N$-acetylglucosaminidase. Strains do not produce $\alpha$-galactosidase, $\beta$-glucuronidase, pyrrolidonylarylamidase or sialidase. Acid is produced from amygdalin, arbutin, lactose, glucose or $\beta$-D- $N$-acetylglucosamine. Acid is not produced from inulin, mannitol, melibiose, raffinose or sorbitol. The majority of strains produce hyaluronidase. Strains are $\beta$-haemolytic and belong to Lancefield group C. Strains were isolated from infections of the human throat (pharyngitis) and clinical specimens (strains M5823 was from an abdominal mass). The DNA G $+\mathrm{C}$ content is 35-37 $\mathrm{mol} \%$.

Description of the type strain. The type strain of Streptococcus constellatus subsp. pharyngis is $\mathrm{MM} 9889 \mathrm{a}^{\mathrm{T}}$ (= NCTC $13122^{\mathrm{T}}$ ), which was isolated from the human throat in a subject with pharyngitis. It has all of the uniform characteristics described above and produces $\beta$-N-acetylglucosaminidase and hyaluronidase. The DNA G + C content is $35 \mathrm{~mol} \%$.

Distinguishing characteristics. The phenotypic characteristics that are useful for distinguishing $S$. constellatus subsp. pharyngis from $S$. constellatus subsp. constellatus, and from the closely related species $S$. 
Streptococcus constellatus subsp. pharyngis subsp. nov.

anginosus and $S$. intermedius, are summarized in Table 2. S. constellatus subsp. pharyngis can be distinguished from $S$. constellatus subsp. constellatus by the ability of the former to produce $\beta$ - $N$-acetylgalactosaminidase, $\beta$ - $N$-acetylglucosaminidase, $\beta$-D-fucosidase, $\beta$-D-galactosidase and $\beta$-D-glucosidase. It can be differentiated from $S$. intermedius by an inability to produce sialidase and by the possession of a 380 bp $16 \mathrm{~S}-23 \mathrm{~S}$ rRNA intergenic spacer, and from $S$. anginosus by the production of $\beta-N$-acctylgalactosaminidase, $\beta-N$ acetylglucosaminidase, $\beta$-D-fucosidase, $\beta$-D-galactosidase, $\alpha$-D-glucosidase, $\beta$-D-glucosidasc and hyaluronidase.

\section{REFERENCES}

Ahmet, Z., Warren, M. \& Houang, E. T. (1995). Species identification of members of the Streptococcus milleri group isolated from the vagina by ID 32 Strep System and differential phenotypic testing. J Clin Microbiol 33, 1592-1595.

Beighton, D., Hardie, J. M. \& Whiley, R. A. (1991). A scheme for the identification of viridans streptococci. $J$ Med Microbiol 35 , 367-372.

Bergman, S., Selig, M. S., Collins, M. D., Farrow, J. A. E., Baron, E. J., Dickersin, G. R. \& Ruoff, K. L. (1995). 'Streptococcus milleri' strains displaying a gliding type of motility. Int J Syst Bacteriol 45, 235-239.

Brenner, D. J. (1978). Characterization and clinical identification of Enterobacteriaceae by DNA hybridization. Prog Clin Pathol 7, 71-117.

Cookson, B., Talsania, S., Chinn, S. \& Phillips, I. (1989). A qualitative and quantitative study of the cellular fatty acids of 'Streptococcus milleri' with capillary gas chromatography. $J$ Gen Microbiol 135, 831-838.

Doitt, C., Grimont, F., Whiley, R. A., Regnault, B., Grimont, P. A. D., Hardie, J. M. \& Bouvet, A. (1994). Ribotypes of the 'Streptococcus milleri-group' allow discrimination between strains of Streptococcus constellatus, Streptococcus intermedius and Streptococcus anginosus. In Pathogenic Streptococci Present and Future, pp. 531-532. Fdited by $\Lambda$. Totolian. St Petersburg, Russia: Lancer Publications

Fox, K., Turner, J. \& Fox, A. (1993). Role of beta-hemolytic streptococci in pharyngitis: incidence and biochemical characteristics of Streptococcus equisimilis and Streptococcus anginosus in patients and healthy controls. J Clin Microbiol 31, 804-807.

Garvie, E. I. (1976). Hybridization between the deoxyribonucleic acid of some strains of hetero-fermentative lactic acid bacteria. Int J Syst Bacteriol 26. 166-122.

Grimont, P. A. D. (1988). Use of DNA reassociation in bacterial classification. Can J Microbiol 34, 541-546.

Jacobs, J. A., Pietersen, H. G., Stobberingh, E. E. \& Soeters, P. B. (1995). Streptococcus anginosus, Streptococcus constellatus and Streptococcus intermedius. Clinical relevance, hemolytic and serologic characteristics. Am J Clin Pathol 104, 547-553.

Kawamura, Y., Hou, X.-G., Sultana, F., Miura, H. \& Ezaki, T. (1995). Determination of 16S rRNA sequences of Streptococcus mitis and Streptococcus gordonii and phylogenetic relationships among members of the genus Streptococcus. Int I Syst Bacteriol 45, 406-408.

Kilpper-Balz, R., Williams, B. L., Luttiken, R. \& Schleifer, K. H. (1984). Relatedness of 'Streptococcus milleri" with Streptococcus anginosus and Streptococcus constellatus. Syst Appl Microbiol5, 494-500.

Lapage, S. P., Sneath, P. H. A., Lessel, E. F., Skerman, V. B. D., Seeliger, H. P. R. \& Clark, W. A. (editors) (1992). International Code of Nomenclature of Bacteria (1990 Revision). Bacteriological Code. Washington, DC: American Society for Microbiology.

Lawrence, J., Yuko, D. M. \& Hadley, W. K. (1985). Incidence and characterization of beta-hemolytic Streptococcus milleri and differentiation from S. pyogenes (group A), S. equisimilis (group C), and large-colony group C streptococci. J Clin Microbiol 22, 772-777.

Marmur, J. \& Doty, P. (1962). Determination of the base composition of deoxyribonucleic acid from its thermal denaturation temperature. $J$ Mol Biol 5, 109-118.

Smith, R. F. \& Willet, N.P. (1968). Rapid plate method for screening hyaluronidase- and chondroitin sulfatase-producing microorganisms. Appl Microbiol 16, 1434-1436.

Vance, D. W. (1992). Group C streptococci: 'Streptococcus equisimilis' or Streptococcus anginosus? Clin Infect Dis 14, 616.

Vandamme, P., Torck, U., Falsen, E., Pot, B., Goosens, H. \& Kersters, K. (1998). Whole-cell protein electrophoretic analysis of viridans streptococci: evidence for heterogeneity among Streptococcus mitis biovars. Int J Syst Bacteriol 48, 117-125.

Wayne, L. G., Brenner, D. J., Colwell, R. R. \& 9 other authors (1987). International Committee on Systematic Bacteriology. Report of the ad hoc committee on reconciliation of approaches to bacterial systematics. Int J Syst Bacteriol 37, 463-464.

Whiley, R. A. \& Beighton, D. (1991). Emended descriptions and recognition of Streptococcus constellatus, Streptococcus intermedius and Streptococcus anginosus as distinct species. Int $J$ Syst Bacteriol 41, 1-5.

Whiley, R. A. \& Hardie, J. M. (1989). DNA-DNA hybridization studies and phenotypic characterization of strains within the 'Streptococcus milleri group'. J Gen Microbiol 135, 2623-2633.

Whiley, R. A., Beighton, D., Winstanley, T. G., Fraser, H. Y. \& Hardie, J.M. (1992). Streptococcus intermedius, Streptococcus constellatus, and Streptococcus anginosus (the Streptococcus milleri group): association with different body sites and clinical infections. $J$ Clin Microbiol 30, 243-244.

Whiley, R. A., Duke, B., Hardie, J. M. \& Hall, L. M. C. (1995). Heterogeneity among 16S-23S rRNA intergenic spacers of species within the 'Streptococcus milleri group'. Microbiology 141, 1461-1467.

Whiley, R. A., Hall, L. M. C., Hardie, J. M. \& Beighton, D. (1997). Genotypic and phenotypic diversity within Streptococcus anginosus. Int J Syst Bacteriol 47, 645-650.

Willcox, M. D. P. (1995). Potential pathogenic properties of the 'Streptococcus milleri' group in relation to the production of endocarditis and abscesses. J Med Microbiol 43, 405-410.

Willcox, M. D. P., Patrikakis, M., Loo, C. Y. \& Knox, K. W. (1993). Albumin binding proteins on the surface of the Streptococcus milleri group and characterization of the albumin receptor of Streptococcus intermedius. J Gen Microbiol 139, 2451-2458.

Winstanley, T. G., Magee, J. T., Limb, D. I., Hindmarch, J. M., Spencer, R. C., Whiley, R. A., Beighton, D. \& Hardie, J. M. (1992). A numerical taxonomic study of the 'Streptococcus milleri' group based upon conventional phenotypic tests and pyrolysis mass spectrometry. J Med Microbiol 36, 149-155. 